\title{
Report stays neutral on deep-sea disposal
}

London. A group of scientists invited by the British government to review the environmental impacts of decommissioning offshore structures has refused to endorse deep-sea disposal as preferable to other options - a conclusion that is believed to have upset Britain's energy minister.

The panel's report, published last week, also questions the basis used by the Shell oil company to select a site in the midAtlantic to dispose of the Brent Spar oilstorage buoy. It recommends that future assessments for decommissioning offshore structures be carried out by an independent panel of scientists.

But the report also confirms the view put forward by Shell that deep-sea disposal of a structure such as the Brent Spar would have a "very small" overall environmental impact, "roughly equivalent to the impacts associated with the wreckage of a fairly large ship".

The 15-member group was set up at the request of Tim Eggar, a minister in the Department of Trade and Industry (DTI), in the wake of a decision last August by Shell to bow to public pressure and abandon plans for the deep-sea disposal of the 14,500-tonne Brent Spar. Eggar, who made public his disapproval of that decision, remains a strong supporter of deep-sea disposal and is widely thought to have expected the scientists to endorse that view (see Nature 381, 99; 1996)

But in the conclusions to its final report, the scientific panel, set up by the Natural Environment Research Council (NERC), and chaired by John Shepherd, director of the Southampton Oceanography Centre, says that nothing in it "should be taken as promoting the deep sea disposal of decommissioned off-shore structures, or of any other wastes".

The report concludes that, from an engineering point of view, "the difficulties and hazards of on-shore disposal are no more than have already been encountered and successfully overcome in other installations". It says that vertical dismantling and disposal on land should not be ruled out.

Despite the relatively low environmental impact of deep-sea disposal, the panel says that "any decision to proceed, or not to proceed", with decommissioning "involves social, economic, aesthetic considerations outside the competence of the group".

Despite having more than six weeks to study the report - publication was delayed by four weeks - the government's response last week was brief. A single-line statement tagged to the end of a press release issued by NERC stated that "the DTI has welcomed the report as a valuable contribution to the decommissioning debate".

A longer response from Eggar was issued later. But no DTI official was available to

answer questions at a press conference held to launch the report - in sharp contrast to the unveiling of a report commissioned by Shell (see Nature 377, 670; 1995) which was attended by several DTI representatives. In the latter report, the Norwegian certification agency, Det Norske Veritas, confirmed that the environmental group Greenpeace had overstated the quantity

\section{IMAGE
UNAVAILABLE \\ IMAGE
UNAVAILABLE FOR COPYRIGHT REASONS}

Water cannon to the right of them: Greenpeace during last year's battle over the disposal of Brent Spar.

of waste on board the Brent Spar.

A spokeswoman for the DTI later denied rumours that Eggar was unhappy with the report's findings. The scientists, she said, had been asked to look at the scientific evidence, not to endorse deep-sea disposal. "They are entitled to say what they want. But at the end of the day any decision on decommissioning is for the government to take."

But the report describes as "unclear" the basis on which Shell selected the North Feni Ridge off the west coast of Scotland to dispose of the Brent Spar. The mid-Atlantic site is a hard, pebbly surface 2,300 metres below the sea. But the report says other sites further afield, which are deeper, softer and 'quieter' - in other words less prone to disturbances such as ocean-bed 'storms' could also have been considered.

The report also addresses the issue of perceived secrecy surrounding the availability of technical documents used to select the Brent Spar's disposal site. Some documents

点 were belatedly made public; others क्ष were classified until recently as "commercial in confidence", according to the report.

For example, when the contract for the site survey was placed, the original agreed requirements between Shell and the government were relaxed, says the report. The original specification required a high-resolution sidescan sonar survey, but this was not carried out. In addition, the results of a low-resolution survey were not made available to the group until February 1996, and omitted a section describing the biology of larger animals.

Eric Faulds, project manager for the Brent Spar decommissioning project, says the UK Scottish Office - "not Shell" chose the site after considering surveys of three possible disposal sites, one of which was at a depth of more than 3,000 metres.

Commercial confidentiality on some of the documents was maintained, he says, in an attempt to recoup the survey costs. A high-resolution sidescan sonar survey, he adds, could not be carried out because the only vessel capable of undertaking such work was in the Far East at the time.

Ehsan Masood

\section{When in Rome - watch out for asteroids}

Boston. With both political and scientific interest growing in potential future collisions between the Earth and either asteroids or planets, a Spaceguard Foundation has been set up in Rome, Italy, to promote the observation of near-Earth objects (NEOs) on potential collision courses.

The nonprofit foundation will coordinate existing NEO searches and sponsor new searches, with the ultimate goal of being an international network of ground-based telescopes similar to that outlined in NASA's 1992 Spaceguard Survey.

More specific plans call for the establishment of a coordination centre - where data would be collected, analysed, distributed and archived - possibly at the Minor Planet Center in Cambridge, Massachusetts, now run by Brian Marsden of the Smithsonian Astrophysical Observatory. Longer-term measures include the standardization of hardware and software and the creation of a dedicated communications network.

The foundation's president, the astronomer Andrea Carusi of IAS-Planetologia in Rome, concedes that the organization has a long way to go before realizing - or even making a significant dent in - its ambitious agenda. At present, the group has access only to a few thousand dollars from membership fees and initial donations. Nevertheless, a fund-raising campaign is being planned in the hope of raising substantial funding from government institutions, space agencies, aerospace companies and private contributions.

The new initiative received a political boost recently when the Council of Europe's Parliamentary Assembly passed a resolution endorsing the establishment of the Spaceguard Foundation, and urging the governments of member states, as well as the European Space Agency, to provide "necessary support". Steve Nadis 